\title{
Systemic Changes in Higher Education
}

\author{
George Siemens \\ Athabasca University \\ Kathleen Matheos \\ University of Manitoba
}

\begin{abstract}
A power shift is occurring in higher education, driven by two trends: (a) the increased freedom of learners to access, create, and re-create content; and (b) the opportunity for learners to interact with each other outside of a mediating agent. Information access and dialogue, previously under control of the educator, can now be readily fulfilled by learners. When the essential mandate of universities is buffeted by global, social/political, technological, and educational change pressures, questions about the future of universities become prominent. The integrated university faces numerous challenges, including a decoupling of research and teaching functions. Do we still need physical classrooms? Are courses effective when information is fluid across disciplines and subject to continual changes? What value does a university provide society when educational resources and processes are open and transparent?
\end{abstract}

Keywords: higher education; freedom of learners; open access; online learning 


\section{Systemic Changes in Higher Education}

After more than a century of pedagogical innovation and several decades of technological advancements, higher education largely retains the systemic structure of previous generations. This system is increasingly mismatched to the needs of society and the affordances of technology in fostering a new scholarship based on open participatory practices.

What is done with information in a particular era is reflected in the institutions created to serve society (McNeely \& Wolverton, 2008). Higher education plays a pivotal role in society, and through research, teaching, and service, seeks to transform and improve society. Since their inception, universities have intersected, interacted, influenced, and been influenced by, the societies in which they exist.

However, universities today face what may be their greatest challenge as they face globalization, expansion, and economic uncertainty, overlaid by emerging technologies that enable the technologically savvy student body to interact in new ways with content and with each other. This confluence of factors requires the academy to rethink and restructure, both what and how they teach and research, and how they intersect with society.

\section{Development of Universities and Roles Played in Society}

Looking into the future of universities often requires a look to the past in order to reflect on the pursuit and dissemination of knowledge, and to determine how institutions served this purpose throughout history. While such functions are seen as the purview of the contemporary academy, such activities were undertaken long before the establishment of the first European university.

\section{From Where We Came}

Universities, as we know them today, have been in existence for over one millennium. However, textual knowledge was developed and disseminated well before the conception of the idea of a university. The Library of Alexandria was established in the 3rd century BCE, and over the five centuries of its existence, it transformed from a predominantly oral, scholarly culture to a portable and heritable written knowledge (McNeely \& Wolverton, 2008). Initially, the library was the depository of Greek culture, but shortly after its establishment, included Hebrew texts translated to Greek and subsequently Christian texts.

Along with the library, which included a systematized catalogue of information, a community of scholars was located within the museum. This community of scholars not only composed text, they also developed the basis for scholarly critique (Heller-Roazen, 2002). It is also suggested that the scholars with the museum gave public lectures to those outside of the museum, disseminating knowledge and information (Argyle, 1974). The library and the museum provided the foundation of university, through the compilation, exploration, and dissemination of knowledge.

Nearly one thousand years later, the first degree-granting universities in Europe were formed. The first of these universities were the University of Bologna (1088) and the University of Paris (c. 1150, later associated with the Sorbonne). However, between the demise of the library and museum of Alexandria and the emergence of the medieval university, both monasteries and madrassahs were keepers and explorers of knowledge. Makdisi (1981) stressed that the madrassahs of Islamic Spain provided foundational elements to the medieval university, as well as provided a temporary home for culture and knowledge of the Hellenistic World. One 
only has to look at the work of Ibn Rushd (1126-1198), whose scholarly work is recognized in both the Arab Islamic and Western Worlds (Urvoy, 1991). He was one of the last great thinkers of Islamic Spain, his lifetime spanning both the decline of Islam on the Iberian Peninsula and the growth of the Western medieval university, with his works embodying both worlds.

McNeely and Wolverton (2008), in their discussion of medieval universities, noted three differences from contemporary universities. First, the Universities of Bologna and Paris were not founded. Rather, they emerged around a group of scholars and students. Second, medieval universities were situated in solely in urban centres. Third, there were no edifices; as essentially the word "university" was used to refer to a group of scholars and students. Students, interested in the pursuit of knowledge, gravitated to the community within their urban centre. However, as the European economy improved in the 11th and 12th centuries, so did mobility and interaction among communities. As a result, students often travelled to new cities to join a university.

Despite the metaphor of the "ivory tower," universities have always intersected with the society in which they are domiciled and have, to a certain extent, changed with society, culminating in the contemporary postmodern university. The 15th century brought the printing press, which would create a turning point for the academy. Publishing abounded, and libraries grew exponentially. The period of 1550-1750 was one of "information explosion" across Europe (Rosenberg, 2003). For example, the field of botany, once a "fact-poor discipline", developed rapidly as naturalists classified and described thousands of plant species and published papers and texts (Ogilvie, 2003).

Early European universities focused on teaching, serving a student body of affluent males. Generally linked to the church, these institutions formed the basis for new world colleges (e.g., Harvard or Yale) and espoused the importance of both civic and religious life. In the early 19th century, Americans returning from graduate study in Germany advocated for the German approach to scholarship and the addition of research to the institution. Prior to this time research was not a primary focus of many universities.

As the universities evolved from church to secular institutions, funded by the state but maintaining academic freedom, the university continued to intersect with society. Moreover, universities expanded beyond Europe, predominantly within countries with which colonial ties existed (Bradby, 1939). Such universities can be characterized in two ways, universities developed in countries where settlers were transplanted, (United States and Canada), and universities developed in countries with ancient civilizations which intersected with or had been influenced by Europe (India).

Within the United States, the Land Grant Act (1861) and the Wisconsin Idea in the late 19th century within the US introduced service aimed at transforming and improving the livelihood of the community (Boyer, 1990). Ten Brook (1875), provides a extensive analysis of the congressional allocation of lands for higher education, citing the University of Wisconsin and defining institution in the future of higher education within the United States. Oxford University also maintained an active extra mural program and built a relationship between intellectuals and the working class, and has been attributed to creating the intelligentsia of labor in the first part of the 20th century (Goldman, 1996). The university now encompassed teaching, service, and research. The university had changed significantly from its medieval roots of a community of scholars and students, where teaching was paramount. The university, through this period of evolution, reflected the changing needs and context of the society it sought to serve. 
Higher education, with a mission of teaching, research, and service, continued to grow, and participation increased rapidly in the 20th century. The 1960s marked the greatest period of expansion and enrolment increases, and access became yet another mandate of most institutions. That decade marked the entry into the post-secondary system of the generation of children born immediately after World War II.

In Canada, this increased population of potential university students resulted in the establishment of several new universities, such as Simon Fraser, York, Laurentian, and Trent. The increased population, coupled with the Federal Student Loan system resulted in a larger, more diverse student population. Simultaneously, Canadian universities saw the emergence of units responsible for providing alternative delivery, with a focus on accessibility. Correspondence and community-based programs emerged, all with the aim of providing higher education to a greater of the population (Rothe, 1986; Seaborne \& Zukernick, 1986).

Changes in higher education reflected the economic, political, social, and cultural changes of the mid to late 20th century. The postwar economic growth provided more funding to education, not only in terms of direct funding to institutions, but also support for participants from those populations normally excluded from higher education. Human rights and integrations were at the forefront of this decade, translating into access to higher education. In the US, AfroAmerican participation grew and Tribal Colleges were established. In Canada, Teacher Education Programs (TEPS) to train Aboriginal teachers were established: programs that are now found across Canadian institutions. In the UK, the Open University was born, starting a trend of open accessible education from which mega universities emerged throughout the developing world. In addition to access, new areas of study emerged, e.g., Aboriginal studies, gender studies, and Hispanic studies. Higher education again reflected the changing society surrounding it, with the exploration of knowledge in new areas, recognizing multiple voices, and the inclusion of voices often absent in the Eurocentric academy.

In 1990, Ernest Boyer reflected on higher education within the US and recognized the competing priorities of teaching, research, and service, concluded that a new vision of scholarship was vital to higher education to make the academy more relevant to society. In 1995, Boyer suggested guidelines that would facilitate the implementation of the new vision of scholarship. He recognized a disconnect within the existing system, and stressed the need to incorporate multiple scholarships in the institution. He emphasized that institutions must change in order to stay relevant to their constituency. He cited examples of enormous societal changes over the last decade, e.g., collapse of the Berlin wall and the Soviet Union, the Oslo Accord, and the succession of the ANC to power (Boyer, 1996). For Boyer, higher education's evolution should be influenced by these significant external changes.

\section{The Contemporary University}

Clearly, the university has evolved since that first library and museum in Alexandria. However, over these last 2,000 years, the changes have been incremental, with individual catalysts. The university of the second millennium is faced with multiple confluent challenges: globalization, mass expansion, and economic uncertainty, overlaid by new technologies connecting learners and content in new ways.

Over two thousand years after Alexandria, 1000 years after the establishment of the University of Bologna, and 600 years since the printing press, the advent of the Internet has had an irrevocable impact on all aspects of higher education, including teaching and learning, 
research, and administration. Levine and Sun (2002) suggest that the Internet will reconfigure the landscape of university education in North America, resulting in three types of institutions: brick, click, and click-and-brick. The brick institutions are the traditional universities that deliver only face-to-face instruction; the click universities are virtual universities that deliver instruction electronically; and click-and-brick institutions deliver programs through a combination of traditional and e-learning modes.

It is not technology alone to which this turbulence is attributed. Rather, this seismic shift, traumatic and fast-paced, is the result of a confluence of interlocking factors. In a recently published book, The American Faculty: The Restructuring of Academic Work and Careers (Schuster \& Finkelstein, 2006) propose that universities are experiencing a revolution-with tremendous consequences. They write,

Everything is in play, as nearly every aspect of academic life is being driven by a host of inter-related developments: dazzling technological advances, globalization that permeates academic boundaries, rapid increase of tertiary students worldwide, expansion of proprietary higher education, a blurring of (the) public/private distinction, and entrepreneurial initiatives on and off campus. (p. xvii)

Just over seven years ago, Preparing for the Revolution (Panel on the Impact of Information Technology on the Future of the Research University, National Research Council, 2002) proposed that information technology would have a profound impact, take place quickly, but in a discontinuous manner. Institutions need to develop the capacity to adapt and change as new modes of knowledge formation emerge. Clearly, the revolution has arrived, as has the time for universities to respond. Gourley (2008) stated, "Scholarship in higher education in this century has to be irrevocably tied to the technology and knowledge media that constitute such important drivers in the society of which we are a part” (Conclusion section, p. 1).

Despite the key role of the "developed" world in higher education, university participation rates in Asia far surpass that of North America. There are approximately 140 million post-secondary students globally, if part-time enrollments are included. China and India have doubled enrollments in the past 10 years, giving China the world's largest higher education system, with some 25 million students (Daniel, Kanwar, \& Uvalic-Trumbic, 2009, p. 2). Moreover, with new wireless technologies, countries like India and China have leapfrogged into the mobile world, in less than a decade. Despite the shifting demographics, the developed world remains a pivotal force in higher education; a responsive change in the academy could have profound impact on higher education around the world and provide a model for the 21st century academy (p.1). Changes to patterns, and habits around information suggest the prospect of direct impact on universities. Universities hold a particularly prominent place in society where learners "come from every quarter for every kind of knowledge" (Halsall, 1998, Section I, p. 11; Centre for Educational Research and Innovation [CERI], 2008a). Governments are often called on to increase investment in higher education during sustained periods of economic downturn (Douglass, 2008).

\section{Looking Toward the Future}

Society creates information-based institutions that reflect the needs (and habits) of a particular era (McNeely \& Wolverton, 2008). What a society does with information determines the types of institutions that are required. Plato's Academy, Aristotle's Lyceum, Alexandria's 
Library, monasteries, universities, and the development of scientific method all mirrored an era's need to organize and socialize around information.

The information cycle, regardless of the era, includes the following components:

1. Creation: Original research or publications

2. Validation: Research and texts are validated through peers

3. Dissemination: Articles, books, and other texts are published and results are shared and disseminated through conferences and academic forums

4. Re-creation: New research builds on existing publications and incorporates ideas advanced by other researchers. Garfield's (1972) journal impact factor suggests the impact of articles_-and thereby journals_can be assessed by evaluating subsequent citations.

5. Context and overlay: Research is applied to various contexts within society, generally referred to as "research commercialization."

The growth of the social and participative web (Eskelsen, Marcus, \& Ferree, 2009, pp. 100-103; Organization for Economic Co-operation and Development [OECD], 2007) and communication technologies (Eskelsen et al., 2009, pp. 1-14, 59-62) have substantially altered the information cycle. These advancements offer new modes of creating, validating, disseminating, and reusing information. Open educational resources, "teaching, learning, and research resources that reside in the public domain or have been released under an intellectual property license” (Atkins, Brown, \& Hammond, 2007, p. 4), allow educators to utilize existing resources in varying contexts.

Through social, networked technologies (see Figure 1), the information cycle has moved from the control of journals and publishers to individuals. Barriers to information access have been reduced due to the development of digital resources. Open educational resources and journals, as well as less formal methods found in blogs, podcasts, wikis, and social networking sites, open wide the doors to engagement with advanced research. Digital information can also be used as an "overlay" onto physical worlds (Maes \& Mistry, 2009), a trend evident in locationbased social networking services such as Gowalla and Foursquare.

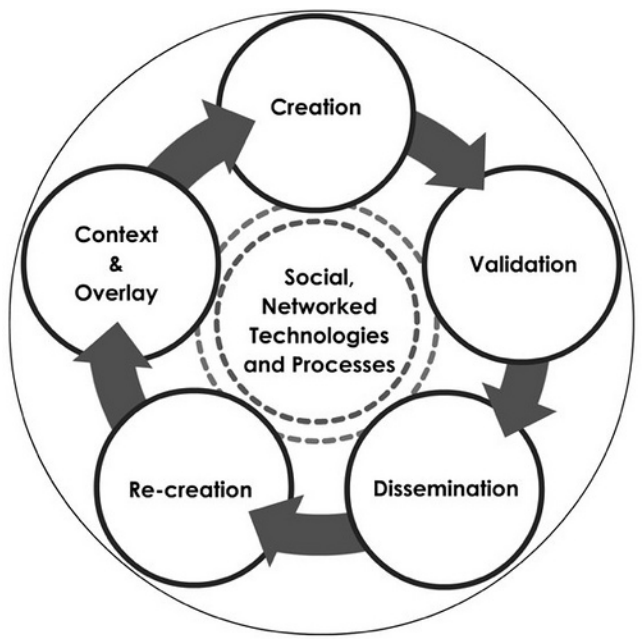

Figure 1. Altered Information Cycle due to participatory technologies 


\section{The Impact on Universities}

Universities "map the reality" of the societies in which they exist (Frank \& Gabler, 2006). When control over information shifts from organizations to individuals, considerations of new models in universities is required, as evidenced by historical transitions of informationbased institutions. As an industry fundamentally concerned with "creating and communicating information” (Carey, 2009, para.1)

\section{Current Pressures of Change}

Higher education faces "unprecedented and ubiquitous change" (Housewright \& Schonfeld, 2008). The current era is one of "the transforming university" (Poole, 2005). Multiple stakeholders are involved in the credibility and success of e-learning: learners, employers, instructors, higher education institution, accreditation bodies, and so on (Wagner, Hassanein, \& Head, 2008). The growth and value of e-learning is directly related to the ability of institutions to attend to the needs of each stakeholder member.

\section{Global}

Global change pressures are large-scale phenomenon, such as global warming, globalization, economics, changing "power centres", impacting all aspects of a society. Higher education has limited influence over these trends, but must be aware of these developments to ensure long-term survival. For example, universities in developed countries are responding to reduced enrolment (driven by slowing population growth in traditional learner markets) by seeking international students (OECD, n.d.) The hegemony of higher education in western countries is being challenged (Daniel, Kanwar, \& Uvalic-Trubmic, 2006), raising the need for increased university partnerships between established and emerging economies. Universities are "at a historical juncture, transitioning from the industrial era to the information era, and from a national perspective to a globalized one" (Freedman, 2006).

\section{Social and Political}

Societal and political factors also contribute to the future of universities. The participative, democratic ideals of open source software are reflected in scholarship, such as Public Library of Science (PLoS ONE) and open educational resources. The process of knowledge production is moving to more social models: "socially distributed knowledge production" (Gibbons, 2002, p. 3), as businesses and organizations are placing greater emphasis on distributed teams and collaboration. Information and knowledge economies place greater prominence of creative work in contrast with traditional manufacturing work (Martin Prosperity Institute, 2009). Demographic changes also contribute to policy shifts.

\section{Technological}

Since its inception, the Internet has experienced tremendous growth (OECD, 2008). The participative web (also known as Web 2.0), mobile phones, social networking services, and netbooks have given individuals greater control over information creation and sharing. Information services like Google Search, Google Scholar, GPS-enabled devices, and e-books, provide learners with improved access and communication opportunities. Technological innovations in bandwidth, storage, processing speed, and software directly impact education (Downes, 2009), creating new opportunities for learner-learner/educator and learner-information interactions. 


\section{Educational}

Educational change pressures are those specific to higher education. Global, social, and technological change factors impact higher education, but research specific to teaching and learning provides greater direction into how the process of learning should best be facilitated. In particular, the development of learning sciences (Sawyer, 2005) as a field offers promise in assisting administrators, educators, and designers in creating effective learning environments. However, as with new and emerging fields, the emphasis on sciences creates some unease among educators. Some researchers have turned to complexity theory to advance education, suggesting that emphasis be placed on the whole system rather than reductionist views often found in "mainstream science" (Mason, 2008). Increased collaboration in a model of "interlocking partnerships among researchers, among universities, and across international borders" (McFadden Allen, 2007, p. 3) promises a new model of not only what it means to be an academic, but also what it means to be an academic institution.

Enrolment in online learning is growing at a significantly faster pace than traditional higher education (Allen \& Seaman, 2008), and the impact of Europe's Bologna Process (Alderman, 2009; Keeling, 2006) now draws increased attention on the state's role in universities.

\section{How Are Universities Around the Globe Responding?}

Universities provide three key value points for learners and society (see Figure 3): content creation and navigation, interactions between learners and faculty, and accreditation. Initiatives, such as MIT’s OpenCourseWare, Yale's Open Learn, and Open University's Open Learn, advance a view that content is no longer strategic value point for higher education. Instead, universities assert that the real point of value in education is the interaction that occurs between students and faculty. Recent large-scale open courses (Siemens \& Downes, 2008) suggest that conversations and connections can also be handled in open formats, potentially reducing this as a key value claim for universities.

Evaluation and accreditation remains a key stronghold for universities, but, if teaching and evaluating (accreditation) were separated-as is evident in software certification where training on software and assessment of competence are often handled by separate organizations - a new value point would be required for higher education. The view that "faculty members must examine their own students" is being questioned, resulting in calls for a "new division of labor in higher education” (Daniel et al., 2009, The Triangle section, p. 2), separating teaching and evaluation.

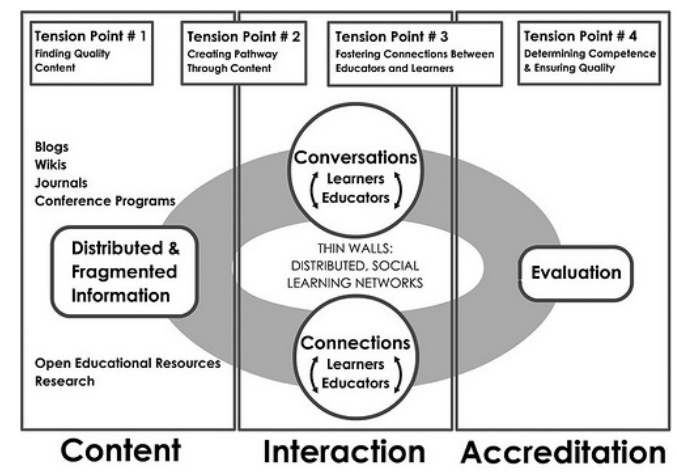

Figure 2. Value points in higher education 


\section{A Model of Future Universities}

Universities are integrated into the core of society. Fundamental systemic change in higher education has been slow to develop, particularly regarding the key mandates of research, teaching and learning, and accreditation. Many activities that occur under these three mandates are potentially transformed due to new modes of information interaction and communication opportunities. Part of the answer may be found in designing intelligent and innovative buildings to take advantage of new technologies (Everett, 2009). This view, however, fails to account for systemic change possible due to open educational resources, emerging technologies, and participatory pedagogies.

It is highly unlikely that one exclusive model of universities will emerge. Instead, as suggested by Centre for Educational Research and Innovation (2006), various scenarios may unfold, including global university networks, universities that emphasize service to their local community, new public responsibilities and governance, and increased corporatization of higher education.

The idea of several models co-existing is not new to higher education, as reflected in the co-existence of monastic and medieval university structures for learning. Following the demise of the library and museum of Alexandria, remnants of this knowledge and information were guarded and explored within monasteries. The rise of the first degree-granting institutions, intersected with the monastic learning, sharing texts and teachers, as well as a religious affiliation of these institutions. Despite the secularization of contemporary higher education, religious colleges are still components of many universities.

Contemporary higher education also reflects both open/distance and traditional systems with students moving between the two systems either within one institution or between institutions to between or among institutions. As more institutions have moved to multiple delivery modes, a convergence of these two systems is apparent.

Within the developing field of open education, a potential scenario of particular importance is the fragmentation of university roles and the increased reliance on technology and distributed organization (see Figure 3).

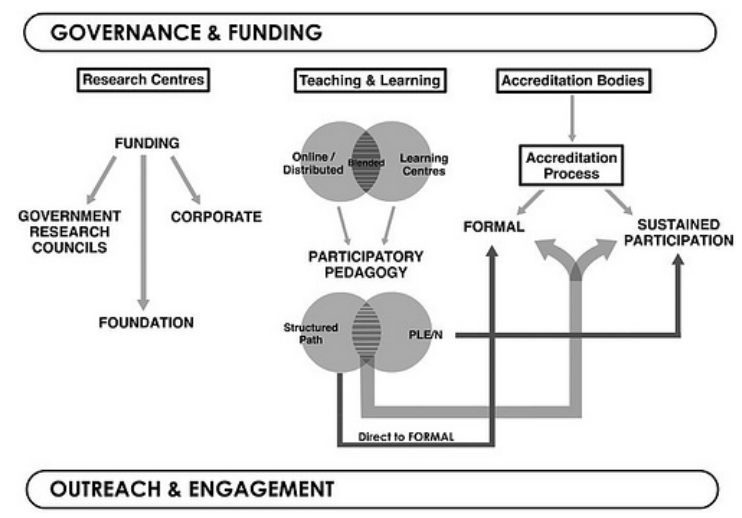

Figure 3. Future Universities: Areas of concern

Governance and funding of research, teaching and learning, and accreditation will continue to rely on government involvement. Universities, after all, have a key role of outreach and engagement - interacting with, responding to, and serving the needs of society. Future higher 
education models, while continuing to rely on government research and service to society, will likely develop in response to global, social and political, technological, and educational trends. Research models and accreditation, largely beyond the scope of this article, provide context to new teaching and learning models.

Online learning has impacted the landscape of higher education. While technology has become pervasive in institutions, wireless access, online library materials, electronic submission of assignments, and learning management systems are all "non-disruptive" or "safe" technologies, allowing faculty to teach in much the same way as they have done for decades. Universities are both comfortable and safe with this use of technology, but do these institutions reflect the society? The world has moved far beyond email and websites. Social networking technologies are pervasive.

Emerging technologies offer faculty additional opportunities to increase engagement with colleagues and learners (Siemens and Tittenberger, 2009). A spectrum of online, blended, and physically based learning centres, each advocating a participatory approach to pedagogy, can serve the needs of all learners (from highly motivated and self-directed to those who prefer greater structure and guidance). Additionally, the "limitless dimensions" of learning (Canadian Council for Learning, p. 4, 2008) can be related to accreditation through personal learning environments and networks (PLE/N). Recognition of only formal learning is a needlessly limiting mindset currently held by higher education.

Many of the assumptions that inform higher education today - such as classrooms, textbooks, physical space, co-location of educators and learners, pairing of research and teaching, bounded curriculum - are called into question by emerging learning theories and technologies. Global and distributed teaching and learning activities are possible due to development of applications (such as Elluminate) that allow for virtual classrooms that permit audio, video, presentations, and break out rooms. Social media such as blogs, social networking software, podcasts, wikis, and others, permit learners to connect with each other (and with educators) from around the world.

\section{Conclusion}

The system of higher education was formed before many of the technological developments that now permit global and continual connectivity. Changed information cycles, new opportunities for social cohesion unrestrained by geography, and distributed research labs offer a prospect for a new era of education. New approaches to research, teaching and learning, and accreditation are possible. The affordances of technology outpace the existing system of education.

Universities in the past have reflected society both temporally and geographically, including how information and knowledge is examined and disseminated. The 1960s resulted in both greater number of physical structures, and increased access of students, beyond what was the traditional body of upper class elite students. Higher education became accessible to individuals from groups often excluded from higher education, transition programs, mature learner support, and student services grew to ensure that these individuals had adequate support during their studies. Access to and completion of the credential were key for these groups of students. Where alternative delivery methods were employed these were primarily correspondence and community-based learning. The highest rates of participation in higher education were in North America, Europe, and Australia. 
The current landscape of higher education reflects both an exponential growth and demographic shift of student participation, with China and India having the greatest number of participants. In other areas, such as the Middle East and Africa, the higher education institutions are taxed to the limit, and will be unable, within the existing structures, to meet the demand. Open and distance learning, in the immediate future, appear to be able to alleviate some of the pressures.

However, as education in the developed world moves in new directions, we must be cognisant of how this move impacts the learners in the developing world. How will learners in these areas access, explore, and contribute to the creation of knowledge? Will social networking technologies and the emergence of next generation technologies further exclude the greatest number of undergraduate learners? Will this new reality result in too few voices connecting and validating knowledge? How can non-Eurocentric voices be heard? One must ensure that there is some democracy in this new model.

Educators and leaders in academia are confronted with important questions. How should institutions of learning be designed to serve the needs participative, social, and global information cycle? What assumptions about the system of higher education need to be abandoned due to technological advancements? How can the vital roles of research and teaching and learning be addressed through distributed means? How can accreditation be broadened to include the full spectrum of formal and informal learning activities?

Addressing these questions will require a significant period of exploration, research, and discourse. Society's learning institutions reflect the needs of a particular era. Libraries, monasteries, universities, and research labs all developed in response to new needs, often driven by technological advances such as the printing press or conceptual advances such as the scientific method. Weller (2009) argues that online technologies and learning enable higher education to comprehend and respond to the changing world and thus remaining relevant to the $21^{\text {st }}$ century society. Failure to recognize the pivotal role of digital technologies will result in institutions at odds with the world in which they operate.

If history serves as a guide, future learning institutions will emerge to reflect how a society creates and shares information, communicates important concepts to those new to a field of study, and generates spaces of discourse for disseminating and extending existing boundaries of knowledge. 


\section{References}

Alderman, C. (2009, April). The Bologna process for U.S. eyes: Re-learning higher education in the age of convergence. Retrieved May 4, 2009 from http://www.ihep.org/assets/files/EYESFINAL.pdf

Allen, E., \& Seaman, J. (2008). Staying the course: Online education in the United States. Retrieved February 20, 2009 from http://www.sloanc.org/publications/survey/pdf/staying the_course.pdf

Archer, W., Garrison, D. R., \& Anderson, T. D. (1999). Adopting disruptive technologies in traditional universities: Continuing education as an incubator for innovation. Canadian Journal of University Continuing Education, 25(1), 13-30.

Argyle, A. W. (1974). The ancient University of Alexandria. The Classical Journal, 69(4), 348350. Retrieved from JSTOR database.

Atkins, D. E., Brown, J. S., \& Hammond, A. L. (2007). A review of the open educational resources (OER) movement: Achievements, challenges, and new opportunities. Retrieved April 30, 2009 from http://www.oerderves.org/wp-content/uploads/2007/03/a-review-of-theopen-educational-resources-oer-movement_final.pdf

Bates, A. W. (2000). Managing technological change. San Francisco: Jossey-Bass.

Boyer, E. (1990). Scholarship reconsidered: Priorities of the professoriate. Princeton, NJ: Princeton University Press.

Boyer, E. (1996). From scholarship revisited to scholarship assessed. Quest, 48, 129-139. Retrieved May 1, 2009 from http://www.vet.utk.edu/enhancement/pdf/feb11new.pdf

Bowman, I. (1971). A design for scholarship. Retrieved May 6, 2010 from http://books.google.ca/books?id=HjFj4U_G18AC\&pg=PP1\&dq=A+Design+for+Scholarshi $\mathrm{p} \& \mathrm{~cd}=1 \# \mathrm{v}=$ onepage $\& \mathrm{q} \& \mathrm{f}=$ false

Canadian Council on Learning. (2008). State of learning in Canada: Toward a learning future. Retrieved April 30, 2009 from http://www.ccl-cca.ca/CCL/Reports/StateofLearning/

Carey, K. (2009). What colleges should learn from newspapers' decline. Retrieved April 30, 2009 from http://chronicle.com/free/v55/i30/30a02101.htm

Centre for Educational Research and Innovation (2008b). Trends shaping education. OECD Publishing.

Centre for Educational Research and Innovation. (2006). Four future scenarios for higher education. Retrieved April 30, 2009 from http://www.oecd.org/document/8/0,3343,en_2649_35845581_37031944_1_1_1_1,00.html

Centre for Educational Research and Innovation. (2008a). Higher education to 2030 (Vol. 1): Demography. Retrieved April 30, 2009 from http://www.oecd.org/document/11/0,3343,en_2649_35845581_41788555_1_1_1_1,00.html

Christensen, C. (1997). The innovator's dilemma. Boston, MA: Harvard Business School Press.

Connectivity Scorecard. (n.d.). Canada connectivity scorecard: Population density slows growth of Canadian connectivity. Retrieved February 20, 2009 from http://www.connectivityscorecard.org/countries/canada 
Daniel, J., Kanwar, A., \& Uvalic-Trubmic, S. (2006, July). A tectonic shift in global higher education. Retrieved February 1, 2009 from http://www.carnegiefoundation.org/change/sub.asp?key=98\&subkey=1841

Daniel, J., Kanwar, A., \& Uvalic-Trumbic, S. (2009). Breaking higher education's iron triangle: Access, cost, and quality. Retrieved on April 30, 2009 from http://www.changemag.org/Archives/Back\%20Issues/March-April\%202009/full-...

David, P. A. (1990). The dynamo and the computer: An historical perspective on the modern productivity paradox. The American Economic Review, 80(2), 355-361.

Davis, A., \& Matheos, K. (2004). Borderless learning: Policy implications for institutions. Paper presented at International Conference on Open and Distance Education, Hong Kong.

Douglass, J. A. (2008). College vs. unemployment: Expanding access to higher education is the smart investment during economic downturns. Retrieved April 30, 2009 from University of California, Berkeley, Center for Studies in Higher Education: http://cshe.berkeley.edu/publications/docs/ROPS.Douglass.CollegeVsUnemp.12.8.08.pdf

Downes, S. (2009). The future of learning: Ten years on. Retrieved February 20, 2009 from http://www.downes.ca/files/future2008.doc

Erskine, A. (1995). Culture and power in ptolemaic Egypt: The Museum and Library of Alexandria. Greece \& Rome, Second Series, 42(1), 38-48. Retrieved May 4, 2009 from http://www.shc.ed.ac.uk/classics/postgraduate/taught/power_and_culture/d...

Eskelsen, G., Marcus, A., \& Ferree, W. K. (2009). The digital economy fact book (10th ed). Retrieved April 30, 2009 from http://pff.org/issues-pubs/books/factbook_10th_Ed.pdf

Everett, R. (2009). Building a better future - planning and designing innovative, intelligent educational buildings. Retrieved April 30, 2009 from http://newsletter.alt.ac.uk/e_article001321590.cfm

Frank, D., \& Gabler, J. (2006). Reconstructing the university: Worldwide shifts in academia in the 20th century. Chicago: Stanford University Press.

Freedman, G. (2008). Unlocking the global education imperative: Core challenges \& critical response. Retrieved February 20, 2009 from http://www.blackboard.com/CMSPages/GetFile.aspx?guid=6032f8df-b6ba-4510-81d2$\underline{3198459529 \mathrm{dc}}$

Garfield, E. (1972). Citation analysis as a tool in journal evaluation. Science, 178(4060), 471479.

Gibbons, M. (2002). Globalization and the future of higher education. In Globalisation: What issues are at stake for universities? Retrieved February 20, 2009 from http://www.bi.ulaval.ca/Globalisation-Universities/pages/actes/GibbonsMichael.pdf

Goldman, L. (1996). Dons and workers: Oxford and adult education since 1850. New York: Oxford University Press.

Gourley, B. (2008, September 26). Scholarship in the digital age, Vice-Chancellor's speech to council. Retrieved April 1, 2009 from http://www.open.ac.uk/vice- 
chancellor/Speeches_3a00_Publications/Speech/Scholarship_in_the_Digital_Age,_ViceChancellor\%27s_Speech_to_Council.html

Halsall, P. (1998). Modern history sourcebook: John Henry Newman: The idea of a University, 1854. Retrieved May 4, 2009 from http://www.fordham.edu/halsall/mod/newman/newmanuniversity.html

Heller-Roazen, D. (2002, Spring). Tradition's destruction: On the library of Alexandria. Obsolescence, 100, 133-153. Retrieved from JSTOR database.

Housewright, R., \& Schonfeld, R. (2008). Ithaka's 2006 studies of key stakeholders in the digital transformation of higher education. Retrieved on April 30, 2009 from http://tinyurl.com/5r5wb6

Keeling, R. (2006). The Bologna process and the Lisbon research agenda: The European Commission's expanding role in higher education discourse. European Journal of Education, 41(2), 55, 203-223.

Kuhn, T. S. (1962). The structure of scientific revolutions. Chicago: University of Chicago Press.

Levine, A., \& Sun, J. C. (2002). Barriers to distance education. American Council on Education Center for Policy Analysis Retrieved on April 30, 2009 from http://www.acenet.edu/bookstore/pdf/distributed-learning/distributed-learning-06.pdf

Maes, P., \& Mistry, P. (2009). TED talks unveiling the "Sixth Sense," game-changing wearable tech [Video]. Retrieved May 4, 2009 from http://www.ted.com/index.php/talks/pattie_maes_demos_the_sixth_sense.html

Makdisi, G. (1981). The rise of colleges: Institutions of learning in Islam and the West. New York: Columbia University Press.

Makdisi, G. (1989). Scholasticism and humanism in classical Islam and the Christian West. Journal of the American Oriental Society, 109(2), 175-182.

Martin Prosperity Institute. (2009, February). Ontario in the creative age. Retrieved from http://martinprosperity.org/media/pdfs/MPI\%20Ontario\%20Report\%202009\%20v3.pdf

Mason, M. (2008). Complexity theory and the philosophy of education. Educational Philosophy and Theory, 40(1), 4-18. doi: 10.1111/j.1469-5812.2007.00412.x

Matheos, K. (2002). Rethinking residency in an age of online learning. Retrieved May 4, 2009 from http://www.cvu-uvc.ca/documents/residencyReport.pdf

McFadden Allen, B. M., (2007). Global collaboration: Benefits and challenges in developing partnerships. In B. M. McFadden Allen, A. Welch, \& Z. Zhen (Eds.), Realizing the global university: Part five (pp. 3-5). Retrieved February 20, 2009 from http://wiche.edu/attachment_library/Global\%20University\%20pdfs/Global\%20University_P art_5.pdf

McNeely, I. F., \& Wolverton, L. (2008). Reinventing knowledge. New York: W.W. Norton \& Co.

Ogilvie, B. W. (2003). The many books of nature: Renaissance naturalists and information overload. Journal of the History of Ideas, 64, 29-40. 
Organization for Economic Co-operation and Development (2008). The future of the Internet economy: A statistical profile. Retrieved on February 20, 2009 from http://www.oecd.org/dataoecd/44/56/40827598.pdf

Organization for Economic Co-operation and Development. (n.d). Australia: World class universities or a world class university system? Retrieved on February 20, 2009 from http://www.oecd.org/document/38/0,3343,en_2649_35961291_40341478_1_1_1_1,00.html

Organization for Economic Co-operation and Development. (2007). Participative web: Usercreated content. Retrieved February 20, 2009 from http://www.oecd.org/dataoecd/57/14/38393115.pdf?contentId=38393116

Panel on the Impact of Information Technology on the Future of the Research University, National Research Council. (2002). Preparing for the revolution: Information technology and the future of the research university. Washington, DC: The National Academies Press.

Poole, D. (2005). The possibilities of university transformation. In R. Nata (Ed.), Issues in higher education (pp. 195-216). Hauppauge, NY: Nova Science.

Rosenberg, D. (2003). Early modern information overload. Journal of the History of Ideas, 64(1), 1-9. doi:10.1353/jhi.2003.0017.

Rothe, P. J. (1986). An historical perspective. In I. Mudgridge \& D. Kaufman (Eds.), Distance education in Canada (pp. 4-24). Kent, ON: Croom Helm.

Sawyer, R. K. (Ed.). (2005). Cambridge handbook of learning sciences. Retrieved from http://www.cambridge.org/us/catalogue/catalogue.asp?isbn=9780511217685

Schumpeter, J. A. (1975). Capitalism, socialism, and democracy. New York: Harper.

Schuster, J. H., \& Finkelstein, J. J. (2006). The American faculty: The restructuring of academic work and careers. Baltimore, MD: The Johns Hopkins University Press.

Seaborne, K., \& Zukernick, A. (1986). Course design and development. In I. Mugridge \& D. Kaufman (Eds.), Distance education in Canada (pp. 37-49). Kent, ON: Croom Helm.

Siemens, G., \& Downes, S. (2008). Connectivism and connective knowledge course. Delivered at University of Manitoba, September to November, 2008. Available from http://tc.umanitoba.ca/connectivism/

Siemens, G., \& Tittenberger, P. (2009). Handbook of emerging technologies for learning. Retrieved from http://umanitoba.ca/learning_technologies/cetl/HETL.pdf

Statistics Canada. (2008, June 12). Canadian Internet use survey. The Daily. Retrieved from http://www.statcan.gc.ca/daily-quotidien/080612/dq080612b-eng.htm

Ten Brook, A. (1875). American state universities, their origin and progress. Retrieved from http://books.google.com/books?id=TZVDAAAAIAAJ\&printsec=frontcover\&dq=history+of +american+universities\&hl=en\&ei=DXrdS_GiEqaaMruHrYUI\&sa=X\&oi=book_result\&ct= result\&resnum=1\&ved=0CEAQ6AEwAA\#v=onepage \&q\&f=false

Urvoy, D. (1991). Ibn Rushd (Averroes) (Trans. O. Stewart). London: Routledge.

van der Wende, M. C. (2003). Globalisation and access to higher education. Journal of Studies in International Education, 7(2), 193. doi: 10.1177/1028315303007002006 
Wagner, N., Hassanein, K., \& Head, M. (2008). Who is responsible for e-learning success in higher education? A stakeholders’ analysis. Educational Technology \& Society, 11(3), 2636.

Weller, M. (2009). Using online learning as a metaphor for educational change. On the Horizon, 17 (3), 181-189 retrieved May 6, 2010 from http://www.emeraldinsight.com/Insight/viewContentItem.do?contentType=Art...

Willis, R., \& Brubacher, J. S. (1997). Higher education in transition: A history of American colleges and universities (4th ed.). Levittown, NY: Transaction Publishers. 